International Journal of Business Management and Economic Review

Vol. 4, No. 02; 2021

ISSN: 2581-4664

\title{
THE ROLE OF SERVICE QUALITY TOWARDS INERTIA AND SATISFACTION BEHAVIOR AND ITS IMPACT ON CUSTOMER LOYALTY OF BUKALAPAK IN BANDA ACEH CITY
}

\author{
Rizki Setiawan*, Sorayanti Utami, Iskandarsyah \\ Management Department, UniversitasSyiah Kuala, Indonesia \\ http://doi.org/10.35409/IJBMER.2021.3247
}

\begin{abstract}
This study aims to measure the effect of service quality (servqual) on inertia behavior and satisfaction and its impact on Bukalapak's consumer loyalty in the city of Banda Aceh. The population in this study were the people of Banda Aceh who used the Bukalapak application. With the purposive sampling method, the sample collected was 150 respondents. The data was processed by using the Structural Equation Modeling (SEM) method to determine the effect of all variables. The results showed that servqualsignificantly affects the inertia behavior, satisfaction, and loyalty of Bukalapak's consumers. Likewise, the influence of inertia and satisfaction behavior significantly affects Bukalapak's consumer loyalty. Besides, the results also showed that inertia and satisfaction behavior mediates the relationship between servqual and Bukalapak's consumer loyalty. The novelty of the research lies in the combination of causality between variables which is used as a model. It is hoped that the next researchers will examine other variables that influence inertia behavior and will have an impact on e-commerce consumer loyalty. In addition, they can also compare how the inertia behavior affects various other ecommerce. Further researchers also are expected to be able to develop this tested model by adding moderation variables such as gender proportions, namely men and women that can affect customer loyalty of e-commerce.
\end{abstract}

Keyword: Servqual, Inertia, Satisfaction, Loyalty

\section{INTRODUCTION}

Indonesia is the largest e-commerce market in Southeast Asia. According to Wearesocial and Hootsuite data, around 90\% of internet users in Indonesia have shopped online. In 2019, the value of e-commerce market capitalization in Indonesia reached USD 21 billion or around IDR 294 trillion. Internet users in Indonesia have made various shopping transactions on e-commerce. The following is data on the number and categories of e-commerce shopping transactions in Indonesia in Figure 1.From this data, it can be seen that the three categories that had the largest increase in transactions in e-commerce are the Toys \& Hobby, Food \& Personal Care, and Furniture \& Appliances category. For Toys \& Hobby products, the number of transactions reached US \$3.16billion, an increase of 67\%. In the Food \& Personal Care category, the number of transactions reached US $\$ 3.17$ billion, an increase of $60 \%$. Furthermore, in the category of Furniture \& Appliances, the number of transactions reached US \$ 2.91 billion, an increase of 
International Journal of Business Management and Economic Review

Vol. 4, No. 02; 2021

ISSN: 2581-4664

57\%. These numbers make Indonesia a market with enormous opportunities for e-commerce organizers in Indonesia. One of the e-commerce sites that Indonesians are interested in is Bukalapak.com. Bukalapak itself is Indonesian e-commerce made by Achmad Zaky which gets a lot of public attention. Based on the Cuponation study quoted from iNews.id (2020), the number of Bukalapak visits was 823.7 million and was ranked 3rd most popular e-commerce site in Indonesia. The following is website visit data on the 5 most popular marketplaces in Indonesia which can be seen in Figure 2 below.

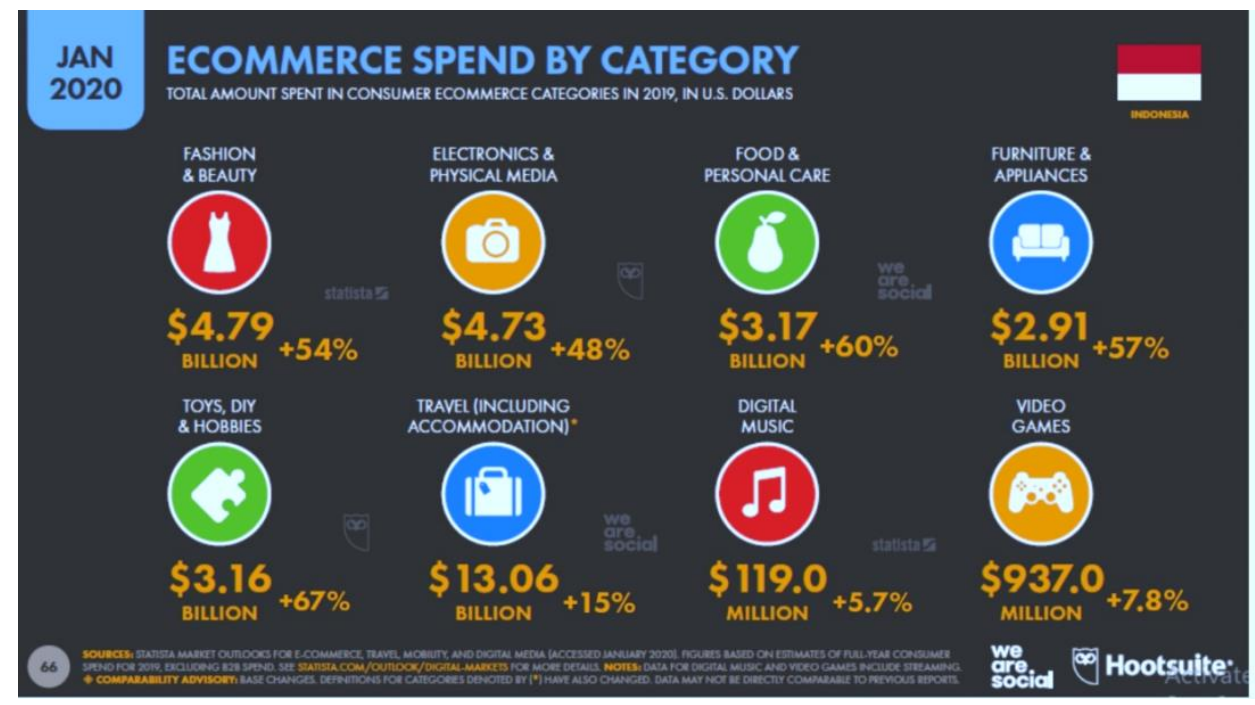

Figure 1.E-Commerce Shopping Category in Indonesia

Source: Hootsuite and We Are Social (2020)

From Figure 2 it can be seen that Shopee's e-commerce increased to rank first in the first quarter in 2020 beating Tokopedia and Bukalapak. Besides, Bukalapak, which previously occupied the second place at the beginning of 2019, must move down to third place until now. In Figure 2 it can also be seen that there is a significant decrease in the number of website visits from the beginning of 2019 on the Bukalapak website. To be able to win the competition and maintain its survival, e-commerce is required to develop the right marketing strategy. There are many kinds of marketing strategies that can be used, one of them is by creating e-commerce customer loyalty. 


\section{International Journal of Business Management and Economic Review}

Vol. 4, No. 02; 2021

ISSN: 2581-4664

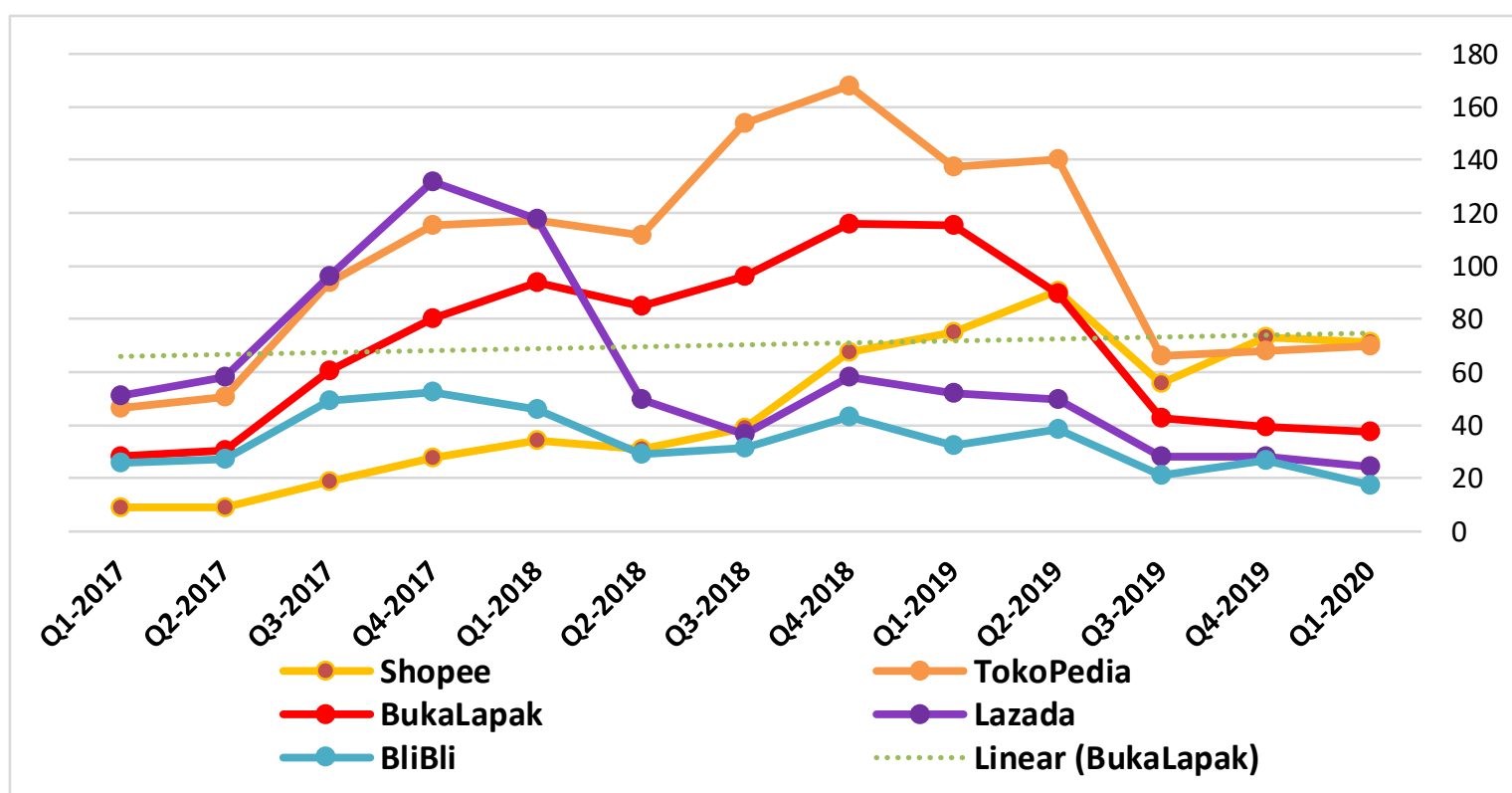

Figure 2.Number of 5 E-Commerce Visits in 2017-2020 (x million)

Source: https://iprice.co.id/insights/mapofecommerce/2020

Loyalty can be interpreted as someone's loyalty to a product. Maintaining customer loyalty means that companies spend less to retain their customers than it costs to get one new customer (Narotama, 2019). This is because the ease of access to various e-commerce allows consumers to compare between traders. This makes it difficult to attract new customers and keep them from turning away to other e-commerce (Rafiah, 2019). In forming customer loyalty, the company seeks to improve several factors that can affect customer loyalty. Some of the factors referred to are satisfaction, consumer behavior, and the quality of service perceived by customers.

Customer satisfaction at this time is no longer separated from the company's vision and mission. In general, a high standard of service will result in higher satisfaction and more frequent repeat purchases (Indra, Regita, \& Purba, 2019). Satisfaction is needed to provide quality services to all customer groups more specifically to fulfill their core needs(Nyan, Rockson, \& Addo, 2020). Customer satisfaction is the key to maintaining them and increasing the company's profitability. Satisfied consumers are less motivated to search for other alternative products and do not want to consider other brands at all so that these consumers become loyal to one product.

Consumer behavior is also a factor that affects customer loyalty, one of which is inertia behavior, which is the laziness of consumers to move from a certain product or service due to consumer habits. At this point, a website that is based on consumer needs and can create a satisfying shopping experience will form a stronger loyalty (Ercis, Yildiz, \& Deveci, 2018). When consumers are familiar with a product and service, they will feel comfortable staying on the product and service and avoid spending extra time and effort, learn about new services, and thus develop an emotional attachment to those products and services (Wang, Ou, \& Chen, 2019). 


\section{International Journal of Business Management and Economic Review}

Vol. 4, No. 02; 2021

ISSN: 2581-4664

Customer inertia behavior can make customers immune to the marketing strategy efforts of competitors (Gray, D'Alessandro, Johnson, \& Carter, 2017). In addition to the main potential effect on loyalty, inertia can also reduce the impact of satisfaction on loyalty. When consumers are in a state of high inertia, sustainable purchasing behavior will occur even though they are not satisfied with the quality of service they receive (Tsai \& Lin, 2017). Therefore, in the context of consumer inertia, all of these conditions must be investigated whether customer loyalty is real loyalty or false loyalty.

To ensure customer loyalty, an efficient service quality (servqual) is required to achieve the desired results. The quality of service will depend on the ability of service providers to fulfill consumer expectations and desires (Nyan et al., 2020). The quality of services that have been created and which will be improved cannot be measured from the company's point of view but from the customer's point of view (Solimun \& Fernandes, 2018). In a customer-oriented industry or business, it is inevitable that servqual is the only determining factor in the existence of the company or industry in being involved in an industry or business that is full of competition, because if servqual is not considered, then the consequence is that customers will move to other industries or businesses of the same type that provide more satisfying service (Rahayu, 2018). In the context of e-commerce, servqual is often called e-servqual. This is to distinguish the dimensions of servqual in e-commerce which are quite different because they also consider technological aspects.

Based on the problems of e-commerce consumer behavior that have been described and the strategies applied by Bukalapak, as well as data proving that Bukalapak is ranked 3 as the most popular e-commerce, this strategy still needs to be studied further related to consumer loyalty and the factors that influence it. Therefore this study aimed to determine the effect of servqual on inertia behavior and satisfaction and its impact on Bukalapak's consumer loyalty in the city of Banda Aceh.

\section{LITERATURE REVIEW}

\subsection{Loyalty}

(Nisar \& Whitehead, 2016) explained that customer loyalty is a customer's commitment to doing business with a certain organization, buying products and services for that organization, and recommending it to the people around them.(Dewi, 2019) explained that loyalty is a repeat purchase over a certain period which is also followed by several indicators such as the possibility to buy and spread positive opinions to others. (Nyan et al., 2020) explained that loyalty is more aimed at non-random behavior that is shown by routine purchases. (Novandy, Rachma, \& Slamet, 2017) defined that loyalty is the amount of consumption and frequency of purchases made by a customer for a company. (Xu \& Du, 2018) explained that loyalty is a feeling of being tied to affection for people, products, or services owned by a company. Another opinion was expressed by (Rohman, Rachma, \& Slamet, 2019), where he argued that a consumer is said to be loyal or loyal if the consumer shows regular purchasing behavior or there is a condition that requires consumers to buy at least twice in a certain time interval. According to(Salah, 2019), he stated that in the context of E-Business Loyalty can be defined as an attitude and commitment that benefits customers towards online retailers which results in repeat buying 


\section{International Journal of Business Management and Economic Review}

Vol. 4, No. 02; 2021

ISSN: 2581-4664

behavior.(Gonçalves, Cândido, \& Feliciano, 2020) explained that loyalty is the attitude and intention to promote word of mouth and the intention to make purchases in the future. (Ercis et al., 2018) explained that e-loyalty is defined as a display of positive attitudes of customers towards e-retailers as a result of repeated purchases. (Fahrika, Rachma, \& Slamet, 2019) defined loyalty as a form of customer loyalty to keep using the same product from a company. Customer loyalty according to (Kotler \& Keller, 2018)was defined as a commitment that is held to make future repurchases or subscriptions to a preferred product or service even though situational influences and marketing efforts have the potential to cause behavior change. From the information above, it can be concluded that what is meant by loyalty is one of the purchasing activities carried out by consumers on the basis of feeling happy and repeated.

\subsection{Inertia}

The concept of inertia according to (Ercis et al., 2018)was defined as individual inactivity, consumer laziness towards any situation, monotonous, their passive approach; that is, the general tendency to take no action and remain inactive. Another opinion put forward by (Rohman et al., 2019) defined consumer inertia as the inertia or laziness that consumers feel about moving from a certain product or service, this is due to habitual factors. According to (Masood, Javaria, \& Awan, 2016), inertia was defined as a pattern of use in which consumers unconsciously use the same product based on their previous experience. (Gray et al., 2017) explained that inertia behavior is a consistent pattern of behavior to buy the same brand almost every time a consumer is shopping, where the brand is bought out of habit and less effort is required. (Gonçalves et al., 2020) defined inertia as a state of individual apathy that contributes to maintaining individual habits and routines and preventing behavior change. (Tsai \& Lin, 2017) explained that inertia refers to a kind of constant consumption model; consumers tend to stick with the same brand not because they seriously consider other brands, but because they are used to it. According to (Wang et al., 2019), inertia is an attitude tendency to maintain the status quo, regardless of alternatives, and thus inhibits consumer switching behavior. ( $\mathrm{Li}, \mathrm{Hu}$, Ranasinghe, Li, \& Cui, 2017) defined inertia as behavior that occurs due to laziness, inactivity, and passivity of consumers. From the above definition, it can be concluded that consumer inertia is the laziness felt by consumers to move from a certain product or service due to consumer habits, even though faced with different alternative choices.

Consumers with a high level of inertia will repeatedly return to the same store, choosing the same product they have bought (Rohman et al., 2019). Consumers who experience inertia do not have a strong motivation to look for alternatives (Tsai \& Lin, 2017). Inertia is a long-term state that arises from past experiences and influences current intentions and future behavior. This is more due to habit factors compared to the benefits he feels for certain products and the costs that must be incurred (Gray et al., 2017). When consumers are accustomed to a product and service, they will feel comfortable staying on the product and service and avoid spending extra time and effort, learn about new services, and thus develop an emotional attachment to those products and services (Wang et al., 2019). (Ercis et al., 2018) explained that there are various reasons for consumers to shop in a state of inertia, there are:

1) Consumers desire to save time. Consumers who behave in this way don't spend time discovering new websites. In other words, they don't compare products and services from 


\section{International Journal of Business Management and Economic Review}

Vol. 4, No. 02; 2021

ISSN: 2581-4664

different stores.

2) Consumers Familiarity with the product. In this way, the consumer continues shopping from the same store in order to take less risk.

3) There is not much difference between certain shops and other alternatives. Consumers argue that all websites market the same goods with no different quality and no different prices.

\subsection{Satisfaction}

Satisfaction is an evaluation of the user's initial trial experience with the service. This evaluation can be in the form of positive feelings or satisfaction, indifference, and negative feelings or dissatisfaction (Hsu \& Lin, 2015). (Lorena, 2018) explained that consumer satisfaction is a consumer response to evaluating perceptions of the difference between initial expectations (certain performance standards) and the actual performance of the product as perceived after product consumption. According to (Rohman et al., 2019), satisfaction is the level of a person's feelings after comparing (performance or results) that is felt compared to expectations. Another opinion according to (Salah, 2019) explained that customer satisfaction is defined as the result of cognitive and affective evaluations, where several standards of comparison are compared to the actual perceived performance. (Nyan et al., 2020) also explained that customer satisfaction or dissatisfaction is a reaction to evaluating the perceived mismatch between expectations and performance in service. (Fahrika et al., 2019) defined satisfaction as the level of a person's feelings after comparing the performance he feels compared to his expectations. (Tsai \& Lin, 2017) explained that customer satisfaction refers to the consumer's fulfillment response, and is an emotional reaction to the gap between what customers expect and what they get. (Wang et al., 2019) defines satisfaction as an emotional response based on a user's overall evaluation of their expectations and experiences stemming from their previous interactions. According to (Indra et al., 2019), customer satisfaction in terms of the customer is about what customers have felt about the services provided compared to what they want. (Ercis et al., 2018) defined customer satisfaction as the extent to which consumer expectations are met. According to (Kotler \& Keller, 2018), satisfaction is "a person's feeling of pleasure or disappointment resulting from comparing the perceived performance (or results) of a product with expectations". Customers will be satisfied when performance is up to expectations. The better the performance, the higher the level of satisfaction the customer has. On the other hand, dissatisfaction will arise when performance is way below customer expectations. From the definition above, it can be concluded that customer satisfaction is the feeling of happiness or sadness that consumers feel in relation to the comparison between expectations and what they receive. including:

(Iskandar, 2017) explained that there are five factors that drive customer satisfaction,

1) Product Quality, the customer is satisfied if after buying and using the product, the product quality is good. Product quality is a global dimension and there are at least 6 elements of product quality, namely: performance, durability, features, consistency, and design.

2) Price, for sensitive customers, usually low prices are an important source of satisfaction because they get a high value of money. For the retail industry, this price component is 


\section{International Journal of Business Management and Economic Review}

Vol. 4, No. 02; 2021

ISSN: 2581-4664

very important and its contribution to satisfaction is relatively large.

3) Quality of service depends on three things, namely systems, technology, and people. One of the popular servqual concepts is ServQual which is believed to have five dimensions, namely reliability, responsiveness, assurance, empathy, and tangible.

4) Emotional factors, pride, self-confidence, a symbol of success, part of an important group of people and so are examples of emotional values that underlie customer satisfaction.

5) Convenience, access to the product or service if it is relatively easy, comfortable, and efficient, the customer will be more satisfied.

\subsection{Service Quality (Servqual)}

According to (Ida Aju Brahmasari, Dipl, \& Panjaitan, 2016), Service Quality (servqual) is seen as one of the components that companies need to realize because it has the influence to bring in new customers and can reduce the possibility of old customers moving to other companies. Servqual is defined as a customer assessment of the superiority or features of a product or service as a whole (Narotama, 2019). (Fahrika et al., 2019) explained that e-servqual is a characteristic of goods and services that are able to support customer needs. In addition, according to (Setyowati \& Suryoko, 2020), servqual in e-commerce called e-servqual is defined as how much the website's ability to provide an effective and efficient shopping experience, payment, and product delivery. (Nyan et al., 2020)definedservqual as the difference between customer expectations about service performance before service encounters and their perceptions of the service received. (Alzoubi, Abdo, Al-Gasaymeh, \& Alzoubi, 2019) explained that servqual is the level of technical capability, design level, transaction processing facilities, and fast response, which meet or exceed customer needs, which can contribute to building good relationships with customers. (Setyowati \& Suryoko, 2020) explained that e-servqual is a website or application that is able to facilitate consumer activities including shopping, purchasing, and delivering products and services effectively and efficiently. (Irwansyah \& Mappadeceng, 2018) defines e-servqual where a website can facilitate the shopping, purchasing and delivery process of goods and services effectively and efficiently. (Prasetyo, 2016) argued that e-servqual aims to make customers feel more efficient in making transactions in terms of costs and time.

Servqual is the most important thing that companies must be considered by the company to in order to provide satisfactory service to their customers. A quality product and quality for customers if the product can meet their needs. Quality is how to find out what creates value for consumers and companies must provide that value. For that, the company must be able to understand its customers and how to define these customer desires correctly. The quality of service can be assessed by consumers by comparing the services they receive and they feel at that time with the wishes or expectations of customers for the services received on the service attributes of a company. If the service perceived by customers is in accordance with the wishes, the servqual can be perceived as good.

\subsection{Hypotheses and Research Model}

Loyalty can be defined as someone's loyalty to a certain product, both goods and services. Maintaining customer loyalty means that companies spend less to retain their customers 


\section{International Journal of Business Management and Economic Review}

Vol. 4, No. 02; 2021

ISSN: 2581-4664

than they cost to get one new customer (Narotama, 2019). In shaping customer loyalty, the company seeks to improve several factors that can affect customer loyalty. Some of the factors referred to are satisfaction, consumer behavior itself, and the quality of service perceived by customers. In general, high-level service will result in high satisfaction and more frequent repeat purchases (Indra et al., 2019). Satisfaction is needed to provide quality services to all customer groups more specifically to meet their core needs (Nyan et al., 2020). In addition, consumer behavior is also a factor that affects customer loyalty, one of which is inertia behavior, which is the laziness of consumers to move from a certain product or service due to consumer habits. This inertia behavior arises due to time pressures and additional costs, consumers who do not like to read through different stores prefer to shop more online at the same store. At this point, a website that is based on consumer needs and is able to create a satisfying shopping experience will form a stronger loyalty (Ercis et al., 2018). Customers define servqual as the overall assessment of a service. To ensure customer loyalty, efficient Quality of Service is needed to achieve the desired results. The quality of service will depend on the ability of service providers to meet consumer expectations and desires (Nyan et al., 2020). Accordingly, it was hypothesized that:

$\mathrm{H}_{\mathrm{a} 1}$ : Servqual, inertia behavior, satisfaction, and consumer loyalty are good.

In using a website in online shopping, a company that provides quality services on its website is following customer desires, it is very likely that the customer will reuse the service in the future. When customers have repeatedly used the website and it gradually becomes a habit, it will form an inertia behavior. Inertia behavior is more of a psychological process in which consumers do not measure their decision process, but rather, justify the habitual act of using the same site over and over. (Adriani \& Warmika, 2019) proved that servqual has a positive and significant effect on the intention to reuse consumers who use Go-Jek services. The same results were also found by (Dzulfiqar, 2017) who stated that servqual had a significant influence on repurchasing habits at Cafe trends in Bandung. Accordingly, it was hypothesized that:

$\mathrm{H}_{\mathrm{a} 2}$ : Servqualsignificantlyaffectsinertia behavior.

Superior servqual and consistency can lead to customer satisfaction, which in turn provides various benefits (Nyan et al., 2020). The quality of service in e-commerce can be seen from two points of view. The first point of view is that the quality of service is seen from the side of the website view which provides easy and fast information to customers and is interesting, the second is the quality of service seen from the work of customer service which provides responsive, helpful service, and is willing to respond to customer inquiries quickly. (Ercis et al., 2018) explained that with the increase in the perceived quality of the website, satisfaction will also increase. (Indra et al., 2019) proved that servqualsignificantly affects customer satisfaction of GrabCar online transportation. (Irwansyah \& Mappadeceng, 2018) also proved that e-servqual has a direct effect on the customer satisfaction of Bukalapak Indonesian consumers. (Fahrika et al., 2019) also proved that online marketing and e-servqual have a significant direct effect on customer satisfaction of the online shop Joyism Malang. Similar results were also found by (Nyan et al., 2020) which showed that servqual was a strong predictor of customer satisfaction in the mobile telecommunications industry in Ghana. Bashir (Fida, Ahmed, Al-Balushi, \& Singh, 2020) also found that servqualsignificantly affects customer satisfaction in Islamic banks. Different results were found by (Lie, Sudirman, Efendi, \& Butarbutar, 2019), which showed that 


\section{International Journal of Business Management and Economic Review}

Vol. 4, No. 02; 2021

ISSN: 2581-4664

there was no significant influence between servqual and customer satisfaction of students using GoJek services. Accordingly, it was hypothesized that:

$\mathrm{H}_{\mathrm{a} 3}$ : Servqualsignificantlyaffectssatisfaction.

Inertia makes consumers avoid looking for further information related to products from unfamiliar websites so that consumers with high inertia will be loyal to the product they are currently using and will repeat purchases on their own. Inertia-driven consumers are also less motivated to consider other website alternatives. When the level of inertia of a customer increases, it shows a tendency to buy a certain product several times. This is because customers may feel uncomfortable about the time and investment it takes to make different choices. Further explained in the research of (Ercis et al., 2018) consumer inertia arises when consumers buy for habitual reasons or because they require less effort. (Anderson \& Swaminathan, 2011) research stated that when a person's level of inertia increases, he tends to show more loyalty. In addition, other research conducted by (Gonçalves et al., 2020) showed that inertia significantly affects loyalty and has a stronger effect in health care than in other service sectors. In addition, (Kuo, $\mathrm{Hu}, \&$ Yang, 2013) research also showed that consumer inertia and satisfaction positively affect repurchase intention, and consumer inertia is more influential than satisfaction in female consumers at two Taiwanese universities who shop online. Research by (Rohman et al., 2019) also found that inertia had a significant effect on the shopping loyalty of Economics and Business students at the Islamic University of Malang in e-commerce. Accordingly, it was hypothesized that:

$\mathrm{H}_{\mathrm{a} 4}$ : Inertia behavior significantly affects loyalty.

To ensure customer loyalty, efficient servqual is needed to achieve the desired results. The quality of service will depend on the ability of service providers to meet consumer expectations and desires (Nyan et al., 2020). Companies are required to be able to provide the best service to customers. (Isnainiyah, Rachma, \& Hufron, 2019) proved that servqualsignificantly affects customer loyalty of Bank BRI Unisma Cash Office. (Irwansyah \& Mappadeceng, 2018) also proved that e-servqual has a direct effect on customer loyalty of Buka Indonesia consumers. The same results were also found by research by (Nyan et al., 2020) which also showed that servqual has a significant positive prediction of customer loyalty in the mobile telecommunications industry in Ghana. (Fida et al., 2020) also found that servqualsignificantly affects customer loyalty in Islamic banks. However, different results were found by (Fahrika et al., 2019) which explained that online marketing and e-servqual did not have a direct effect on customer loyalty of the online shop Joyism Malang. Different resultwas also shown in the research of (Narotama, 2019) where servqual does not have a significant effect on customer loyalty. This happened because each bank had the same Standard Operating Procedure (SOP) so that customers perceive it was as a normal. Research The same results were also found by (Lie et al., 2019) which showed that there was no significant influence between servqual and customer loyalty of students using GoJek services. Accordingly, it was hypothesized that:

$\mathrm{H}_{\mathrm{a} 5}$ : Servqualsignificantlyaffectsloyalty.

When customers are satisfied with a website, they will be more willing to interact with the website side in the future so that they become loyal and loyal customers. Customers who are 


\section{International Journal of Business Management and Economic Review}

Vol. 4, No. 02; 2021

ISSN: 2581-4664

very satisfied will become loyal and can make repurchases (Indra et al., 2019). Satisfied customers will usually avoid seeking uncertainty about whether a customer can receive the same satisfaction and service from other web sites. This also triggers customers to continue using the same website in the future. (Gani, 2018) also proved that e-Satisfaction and e-Trust have a positive and significant effect on e-Loyalty in female consumers who make online shopping transactions. Similar resultwas also found in (Rafiah, 2019) study where customer satisfaction and customer trust have a significant and positive effect on e-commerce consumer loyalty. Research by (Rohman et al., 2019) also found that satisfaction significantly affects shopping loyalty of students of the Faculty of Economics and Business, Islamic University of Malang in ecommerce. (Iskandar, 2017) showed the relationship between satisfaction and loyalty, namely interaction quality, has a significant positive effect. (Narotama, 2019) also found that satisfaction significantly affects loyalty to customers of Bank BRI SoekarnoHatta Branch Office Malang. A different thing is found in the research of (Nyan et al., 2020) which showed that customer satisfaction does not have a direct significant effect on customer loyalty in the mobile telecommunications industry in Ghana. Accordingly, it was hypothesized that:

$\mathrm{H}_{\mathrm{a} 6}$ : Satisfaction significantly affects loyalty.

In using a product, the service felt by the customer if it is in accordance with the wishes, the servqual can be perceived as good. When customers have used it repeatedly and become a habit, inertia behavior will appear. By continuing to increase inertia behavior in a product, loyalty will be formed. When consumers are in a high state of inertia, sustainable purchasing behavior will occur even though they are not satisfied with the quality of service they receive (Tsai \& Lin, 2017). The research of (Amoroso, Ackaradejruangsri, \& Lim, 2017) proved that inertia is the strongest factor among all constructs in predicting consumer loyalty and continuation intention, either as a mediator variable or directly in mobile wallet application users in Thailand. In addition, (Hu, Cheng, Chiu, \& Hong, 2011) also found that apart from being positively influenced by customer satisfaction, customer loyalty will be more influenced by inertia in the fast-food industry in Taiwan. In the relationship between customer satisfaction and customer loyalty, relationship inertia plays a role as a key mediator. Similar research conducted by (Lee, Hwang, Tran, \& Keel, 2019) also found that the role of inertia mediation is significant and the latent interaction effect of loyalty and inertia on service duration is also significant for cellular service subscribers. Accordingly, it was hypothesized that:

$\mathrm{H}_{\mathrm{a} 7}$ : Inertia behavior mediates the relationship between servqual and loyalty.

In website-based services, companies that provide higher e-servqual to customers will lead to customer satisfaction, and in the long term, it will certainly result in customer loyalty (Irwansyah \& Mappadeceng, 2018). (Ercis et al., 2018) explains that the perceived servqual in the online environment shows an increase in satisfaction and as a result of this satisfaction, their loyalty to the website also increases. When consumers have experienced good and friendly servqual, and feel satisfaction with the quality of service provided to these products, these consumers will give positive traits. When a positive character has emerged, there will be a sense of loyalty to a certain brand. (Irwansyah \& Mappadeceng, 2018) also proved that e-servqual affects customer loyalty through customer satisfaction at Buka Indonesia. Other research conducted by (Wicaksono \& Untoro, 2015) also proved that customer satisfaction is a mediator 


\section{International Journal of Business Management and Economic Review}

Vol. 4, No. 02; 2021

ISSN: 2581-4664

in the relationship of servqual and price fairness to customer loyalty of IM3 card provider users. Research by (Nyan et al., 2020) also proved that customer satisfaction mediates the effect of servqual on customer loyalty in the mobile telecommunications industry in Ghana. Similar research conducted by (Narotama, 2019) found a mediating effect of customer satisfaction in the relationship of servqual to customer loyalty. Research by (Lie et al., 2019) also showed that there is a mediating effect of satisfaction between the relationship of servqual to customer loyalty of students using GoJek services. (Fahrika et al., 2019) also proved the satisfaction variable as an intervention in online marketing and e-servqual relationships with loyalty. However, different research results are proven in research by (Susanto, Rachma, \& Hufron, 2018) which explained that satisfaction does not mediate the relationship between servqual and customer loyalty. This is because high servqual will directly affect customer loyalty without having to go through satisfaction as the mediator. Accordingly, it was hypothesized that:

$\mathrm{H}_{\mathrm{a} 8}$ : Satisfaction mediates the relationship between servqual and loyalty.

Based on the conceptual explanation that underlies this research, a conceptual framework can be described as in figure 3 below.

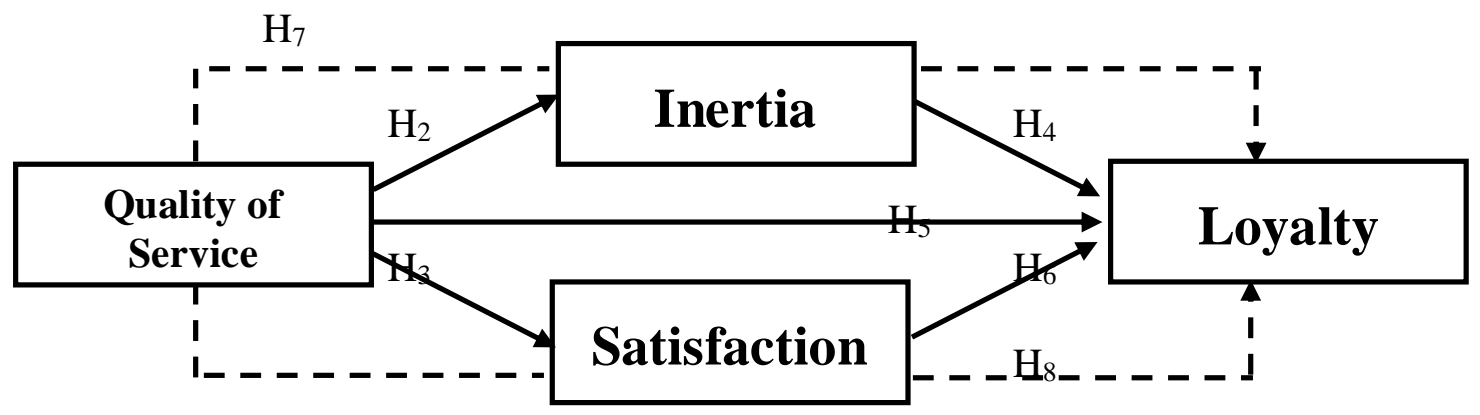

Figure 3.Research Theoretical Framework

\section{METHOD}

\subsection{Population and Sample}

The population in this study were all Banda Aceh city people who use Bukalapak in carrying out their online shopping activities. Furthermore, in the sampling in this study using the purposive sampling method, namely the criteria that must be owned by the sample in order to be selected are the people of Banda Aceh City who use Bukalapak who have done shopping more than once. This is in accordance with the opinion of (Rohman et al., 2019), it was explained that a consumer is said to be loyal if the consumer shows regular buying behavior or there is a condition that requires consumers to buy at least twice in a certain time interval.

In determining the number of samples to be studied, researchers used the recommendations of (F. Hair Jr, Sarstedt, Hopkins, \& G. Kuppelwieser, 2014) which states that the number of samples of observation data is at least 5 times the parameter to be estimated or at least 100. In this study, there were 24 question items from the variable indicators used. So the sample that must be taken is $5 \times 24$ with a total of 120 samples. Besides, the sampling formula 


\section{International Journal of Business Management and Economic Review}

Vol. 4, No. 02; 2021

ISSN: 2581-4664

according to (Riduwan \& Kuncoro, 2014) if the population is not known with certainty is as follows:

Information : $\mathrm{n}=$ number of samples

$$
\begin{aligned}
& n=\left(\frac{(Z a / 2) x \sigma}{e}\right)^{2} n=\left(\frac{1.96 \times 0.25}{5 \%}\right)^{2} \\
& n=96.04 \text { rounded off } 100
\end{aligned}
$$

$\mathrm{Za} / 2=$ value from normal distribution table with $95 \%$ confidence level

$\sigma=$ standard deviation $25 \%$

$\mathrm{e}=$ error $($ error limit $=5 \%)$

Furthermore, based on some of the opinions of previous researchers, the sample in this study was taken as many as 150 respondents to avoid errors from the collected questionnaire data.

\subsection{Data Collection and Analysis Technique}

In collecting research data that is appropriate to the object to be studied, the writer will carry out activities to collect data with the help of a questionnaire. The questionnaire used to collect data is a type of choice that makes it easy to answer and provide responses, because alternative answers are available and do not take long to provide answers. In the questionnaire, respondents are asked to state their level of agreement following a Likert scale with intervals of 1-5. Measurement of variables using an interval scale, which is a measuring tool that can produce measurements that allow the calculation of the average, standard deviation, statistical test parameters, correlation and so on (Ferdinand, 2014).

Furthermore, the collected data will be analyzed using The Structural Equation Modeling (SEM) technique. The Structural Equation Modeling (SEM) hypothesis testing model is a statistical technique that allows testing a series of relatively "complicated" relationships simultaneously (Ferdinand, 2014). Furthermore, to test the effect of mediation, a mediation analysis will be carried out using the Baron and Kenny approach (Ghozali, 2017) through the SPSS application and the Sobel test.

\subsection{Operational Variables}

The variable operation is needed to describe the research variables into concepts, dimensions, indicators and measures that are directed to obtain the values of other variables. The variables, definitions and indicators used in this research are as follows:

1. Independent Variable

Independent variables are variables that affect or cause changes or the emergence of the dependent variable. So in this study the independent variable is Servqual (X). The following are the dimensions and indicators of servqual(Alzoubi et al., 2019):

1) Reliability, which refers to the ability of e-to perform the promised services appropriately and accurately. The indicators are as follows:

- E-tailers are able to perform the promised services precisely

- E-tailers are able to perform the promised services accurately 


\section{International Journal of Business Management and Economic Review}

Vol. 4, No. 02; 2021

ISSN: 2581-4664

2) Responsiveness, which refers to the speed of response and the e-tailer's willingness to help customers. The indicators are as follows:

- Speed of response from etailers

- Willingness of e-tailers to help customers

3) Privacy/Security, which refers to the protection of personal and financial information. The indicators are as follows:

- E-tailers protect customers personal information

- E-tailers protect customers financial information

4) Information Quality/Benefit, which refers to the conformity of information with customer needs and objectives. The indicators are as follows:

- Information provided by e-tailers according to customer needs

- Information provided by e-tailers according to customer objectives

5) Ease of Use/Usability, which refers to the effort required by the customer to gain access to available information. The indicators are as follows:

- The effort required by customers to gain access to available information

6) Web Design, refers to the aesthetic features, content and structure of the online catalog. The indicators are as follows:

- Features contain aesthetic value

- The content shown on the site

- The catalog structure is listed on the site.

2. Dependent Variable

The dependent variable is the variable that is influenced or which becomes the result because of the independent variable in accordance with the problem to be studied, so what will become the dependent variable is Loyalty (Y). The following are indicators for measuring loyalty in this study (Gonçalves et al., 2020):

1) Saying positive things to other people

2) Recommend to someone who asks for advice

3) Encourage friends and relatives to use it

4) Consider the first choice when you need it

5) Intend to use it in the future.

3.Mediation Variable

The mediating or intervening variable is an intermediate variable, which serves to mediate the relationship between the independent variable and the dependent variable. So in this study the mediating variables are as follows:

- Inertia behavior (Z1), following indicators of inertia behavior (Ercis et al., 2018):

1) Switching to another website is very troublesome

2) Access the shopping website very intuitively when shopping

3) The time, money and effort costs of switching to another website are high.

- Satisfaction (Z2), an indicator of satisfaction (Wang et al., 2019) is as follows:

1) Satisfied with the application.

2) The application has met expectations.

$3)$ The experience with the application was very enjoyable.

4) Application does a satisfying job of meeting my needs. 
International Journal of Business Management and Economic Review

Vol. 4, No. 02; 2021

ISSN: 2581-4664

\section{RESULT}

\subsection{Respondent Characteristics}

Based on the data collected, the following characteristics of the respondents in this study are shown in table 1 below.Based on Table 1. it can be seen that the characteristics of respondents based on gender are more dominated by women, namely as many as 103 people or $68.7 \%$ of the total respondents, while men are only 47 people or $31.3 \%$. Based on the age

Table 1. Descriptive Statistics of Respondent Characteristics

\begin{tabular}{|c|c|c|c|}
\hline No & Information & Frequency & Percentage \\
\hline 1 & $\begin{array}{l}\text { Gender: } \\
\text { - Man } \\
\text { - Woman }\end{array}$ & $\begin{array}{l}47 \\
103\end{array}$ & $\begin{array}{l}31.3 \% \\
68,7 \%\end{array}$ \\
\hline 2 & $\begin{array}{l}\text { Age (Years Old) : } \\
\text { - }<20 \\
\text { - } 20-24 \\
\text { - } 25-29 \\
\text { - } 30-34 \\
\text { - } 35-39 \\
\text { - } \geq 40\end{array}$ & $\begin{array}{l}6 \\
47 \\
59 \\
13 \\
15 \\
10\end{array}$ & $\begin{array}{l}4.0 \% \\
31.3 \% \\
39,3 \% \\
8,7 \% \\
10.0 \% \\
6.7 \%\end{array}$ \\
\hline 3 & $\begin{array}{l}\text { Education: } \\
\text { - Senior High School } \\
\text { - Diploma III } \\
\text { - Diploma IV/Strata I } \\
\text { - Strata II/Masters }\end{array}$ & $\begin{array}{l}29 \\
20 \\
98 \\
3\end{array}$ & $\begin{array}{l}19,3 \% \\
13.4 \% \\
65.3 \% \\
2.0 \%\end{array}$ \\
\hline 4 & $\begin{array}{l}\text { Purchased Amount: } \\
\text { - } 2 \text { times to } 3 \text { times } \\
\text { - } 4 \text { times to } 5 \text { times } \\
\text { - } \geq 6 \text { times }\end{array}$ & $\begin{array}{l}35 \\
71 \\
44\end{array}$ & $\begin{array}{l}23.3 \% \\
47.3 \% \\
29,4 \%\end{array}$ \\
\hline
\end{tabular}

Source: Primary Data, 2020 (Processed)

of the respondents, there are 6 people under the age group. The age group of 20 years to 24 years is 47 people. There were 59 people aged 25 to 29 years old and were the most respondents of all age groups, namely $39.3 \%$. There are 13 people in the 30 to 34 year age group. There are 15 people aged 35 years to 39 years and the rest are more than or equal to 40 years, namely 10 people. Based on educational background, Diploma IV/Strata 1 is the most dominant education compared to other educational backgrounds, namely as many as 98 people or $65.3 \%$. Furthermore, high school education was 29 students (19.3\%), Diploma III education was 20 people (13.4\%), and Masters education was 3 people (2.0\%). Based on the number of respondents who have shopped, 35 respondents or $23.3 \%$ of the total respondents have shopped 2 


\section{International Journal of Business Management and Economic Review}

Vol. 4, No. 02; 2021

ISSN: 2581-4664

to 3 times. Respondents who had shopped 4 to 5 times were 71 people (47.3\%) and the rest spent more or the same as 6 times, namely 44 people (29.4\%).

\subsection{Descriptive Research}

The size used in descriptive statistics depends on the type of measurement scale construct used in the study (Ghozali, 2017). In this study, the type of scale used is the Likert scale where the average answer to the respondent is 5 classes. According to (Sudjana, 2002), the length of each class interval from 5 classes for all research variables with a predetermined category is 0.8 . Following are the responses of respondents to all variables in this study can be seen in table 2 below. Table 2 shows the overall average value of the respondent's level of agreement regarding the variables in this study is a good assessment category. This shows that respondents rated good for all statements regarding loyalty, servqual, inertia behavior, and satisfaction at Bukalapak. The variable that gets the lowest average value is servqual (X) with an average of 3.94. From the results of the above calculations, the value $\gamma 1$ of all research variables is greater than 3.40 , thus it can be stated that the hypothesis Ha1 is accepted, namely servqual, inertia behavior, satisfaction, and consumer loyalty are good.

Table 2. Descriptive Variable

Source: Primary Data (processed), 2020

\begin{tabular}{|l|l|l|}
\hline No & Variable & $\begin{array}{l}\text { Average } \\
\text { Response }\end{array}$ \\
\hline 1 & Loyalty & $\mathbf{4 . 0 0}$ \\
\hline 2 & Quality of Service & $\mathbf{3 . 9 4}$ \\
\hline 3 & Inertia & $\mathbf{4 . 0 9}$ \\
\hline 4 & Satisfaction & $\mathbf{4 . 1 5}$ \\
\hline
\end{tabular}

\subsection{Testing the Goodness Of Fit Index}

Based on the results in table 3, it is known that the Chi-square value is 379.151 and the probability value is 0.139 which is above> 0.05 ; RMSEA value 0.060 less than 0.08 ; the GFIvalue is 0.823. which is below 0.90; AGFI value of 0.786 below 0.90; TLI value of 0.968 which is above 0.95; and the CFI value also shows 0.972 which is above 0.95 . Even though the GFI and AGFI values are at a marginal value below the critical value, according to Hair et al (2010), the GFI and AGFI values are close to the recommended values, so the model is still feasible to continue. In addition, the opinion of (Santoso, 2014) states that the model is already fit, supported by the probability test result of 0.139 which is far above 0.05 . which means that the above model is completely fit. Thus it can be concluded that the overall model is fit and acceptable and suitable for use for further analysis. 
International Journal of Business Management and Economic Review

Vol. 4, No. 02; 2021

ISSN: 2581-4664

Table 3. Evaluation Criteria for Goodness of Fit Indices

\begin{tabular}{|l|l|l|l|}
\hline Criteria & $\begin{array}{l}\text { Model } \\
\text { Results }\end{array}$ & Critical Value & $\begin{array}{l}\text { Model } \\
\text { Evaluation }\end{array}$ \\
\hline Chi-Square $\chi 2$ (CMIN) & $\mathbf{3 7 9 . 1 5 1}$ & $\begin{array}{l}\text { Expected to be smaller } \\
\text { han the sample }\end{array}$ & Not Good \\
\hline Probability (P) & $\mathbf{9 . 1 3 9}$ & $>0.05$ & Good \\
\hline RMSEA & $\mathbf{9 . 0 6 0}$ & $<0.08$ & Good \\
\hline GFI & $\mathbf{9 . 8 2 3}$ & $>0.90$ & Not Good \\
\hline AGFI & $\mathbf{9 . 7 8 6}$ & $>0.90$ & Not Good \\
\hline TLI & $\mathbf{9 . 9 6 8}$ & $>0.95$ & Good \\
\hline CFI & $\mathbf{9 . 9 7 2}$ & $>0.95$ & Sood \\
\hline
\end{tabular}

Source: Primary Data, 2020 (processed)

\subsection{Hypothesis Testing}

Hypothesis testing is carried out using the Critical Ratio (C.R) value at a significant level of 0.05 . If the value of Critical Ratio (C.R) $>1.967$ and the probability value (p) $<0.05$ then Ho is rejected and the alternative hypothesis (Ha) in this study is accepted. To get this value, data processing is carried out with AMOS as shown in Figure 4 below. The test results can be seen more clearly in table 4 below. The results of the analysis show that servqualsignificantly affects the inertia, satisfaction, and loyalty of the people of Banda Aceh who use Bukalapak. For more information, it will be discussed as follows.

Table 4. Hypothesis Testing Results

\begin{tabular}{|c|c|c|c|c|c|c|c|}
\hline & & & Estimate & $\begin{array}{l}\text { Standardized } \\
\text { Estimate }\end{array}$ & S.E. & C.R. & $\mathbf{P}$ \\
\hline Inertia (Z1) & $<--$ & Quality of Service $(\mathrm{X})$ & 1.231 & .967 & .081 & 15.294 & $* * *$ \\
\hline Satisfaction (Z2) & $<---$ & Quality of Service (X) & 1.127 & .956 & .076 & 14.764 & $* * *$ \\
\hline Loyalty (Y) & $<---$ & Satisfaction (Z2) & .805 & .684 & .192 & 4.191 & $* * *$ \\
\hline Loyalty (Y) & $<---$ & Inertia $(\mathrm{Z} 1)$ & .904 & .828 & .258 & 3.497 & $* * *$ \\
\hline Loyalty (Y) & $<--$ & Quality of Service (X) & .675 & .485 & .343 & 1.970 & .049 \\
\hline
\end{tabular}

Source: Primary Data, 2020 (processed)

1. The Effect of Servqual on Inertia

The results of hypothesis testing show that the servqual variable on inertia has an influence of 0.967 with a critical ratio (C.R) of 15.294> 1.967 at a significant level of $0.000>0.05$. This explains that if the quality of service increases by 1 point, the inertia behavior will increase by $96.7 \%$ and this effect is significant. Thus it can be stated that the hypothesis $\mathrm{Ha} 2$ is accepted, that is the quality of service significantly affects the 
International Journal of Business Management and Economic Review

Vol. 4, No. 02; 2021

ISSN: 2581-4664

inertia behavior of Bukalapak consumers in the city of Banda Aceh.

2. The Effect of Servqual on Satisfaction

The results of hypothesis testing show that the servqual variable on satisfaction has an influence of 0.956 with a critical ratio (C.R) of 14.764> 1.967 at a significant level of $0.000>0.05$. This explains that if the quality of service increases by 1 point, then customer satisfaction will increase by $95.6 \%$ and this effect is significant. Thus it can be stated that the hypothesis $\mathbf{H a} 3$ is accepted, That is the quality of service significantly affects customer satisfaction in the city of Banda Aceh.

3. The Effect of Inertia on Loyalty

The results of hypothesis testing show that the inertia variable on loyalty has an influence of 0.828 with a critical ratio (C.R) of 3.497> 1.967 at a significant level of $0.000>0.05$. This explains that if the inertia behavior increases by 1 point, then consumer loyalty will increase by $82.8 \%$ and this effect is significant. Thus it can be stated that the hypothesis Ha4 is accepted, that is, inertia significantly affects consumer loyalty in the city of Banda Aceh.

4. The Effect of Servqual on Loyalty

The results of hypothesis testing show that the variable of servqual on loyalty has an influence of 0.485 with a critical ratio (C.R) of 1.970> 1.967 at a significant level of $0.049>0.05$. This explains that if servqual increases by 1 point, consumer loyalty will increase by $48.5 \%$ and this effect is significant. Thus it can be stated that the hypothesis Ha5 is accepted, namely servqualsignificantly affects Bukalapak's consumer loyalty in Banda Aceh City.

5. The Effect of Satisfaction on Loyalty

The results of hypothesis testing show that the satisfaction variable on loyalty has an influence of 0.682 with a critical ratio (C.R) of 4.191>1.967 at a significant level of $0.000>0.05$. This explains that if satisfaction increases by 1 point, loyalty will increase by $68,2 \%$ and this effect is significant. Thus, it can be stated that the hypothesis Ha6 is accepted, that issatisfaction significantly affects consumer loyalty in the city of Banda Aceh.

\subsection{Mediation Hypothesis Testing}

In this study, there are intervening variables (mediation), namely inertia behavior and satisfaction. The mediation test is used to prove the role of inertia behavior and satisfaction as a mediating variable, which serves to mediate the relationship between servqual variables and loyalty.

Verification of the indirect effect hypothesis between the variables contained in the model will be done using the (Baron \& Kenny, 1986) approach and the Sobel Test. Furthermore, we will explain the effect/relationship from before the mediation effect to after the mediation effect (inertia) with the Baron and Kenny approach between servqual variables to loyalty which can be seen in table 5 below:

Based on the results of the regression analysis in table 5, it is identified that in model 1 there is a positive and significant relationship between the servqual variable and loyalty, which is 


\section{International Journal of Business Management and Economic Review}

Vol. 4, No. 02; 2021

ISSN: 2581-4664

indicated by $\beta 1=0.912$, and $\operatorname{Sig}<0.05$. When the relationship between servqual and loyalty is included in the mediating variable in model 2 , namely inertia behavior, it shows a significant relationship too $(\beta 2=0.334, \mathrm{p}<0.05)$. The description above also provides information about changes in the $\beta$ value of the first servqual which was previously 0.912 ; after entering the mediating variable, the $\beta$ value of servqual became 0.334 . Based on the above results associated with the method of Baron and Kenny, it can be explained that the inertial behavior variable has a role as partial mediation. This is because the relationship between the servqual variable and the loyalty variable before and after the inclusion of the mediating variable is equally significant. This supports the hypothesis that has been put forward in this study.

Table 5. Results of Regression Analysis of the Effect of Inertia Mediation

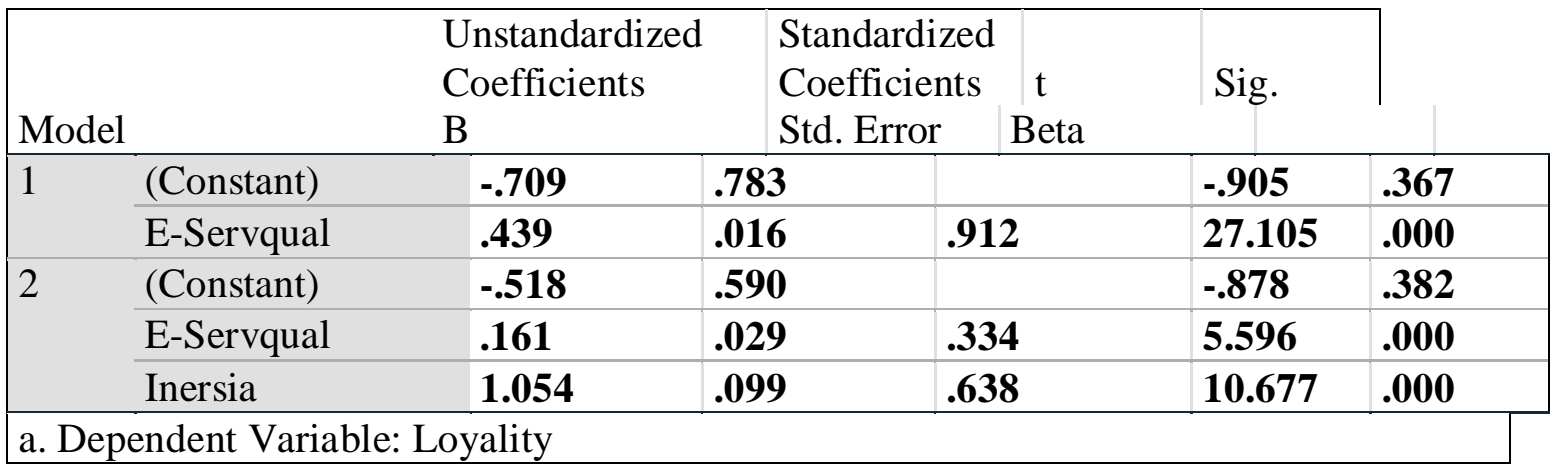

Furthermore, testing the mediation hypothesis is also carried out using a procedure developed by (Sobel, 1982) and is known as the Sobel test. The following is testing the mediating effect of the inertia variable which can be explained as follows. Based on Figure 5 above is a model formed from the results of the first and second regressions so as to form a path analysis model with the inertia variable as the mediator. The $\mathrm{z}$ value of the sobel test cannot be generated directly from the regression results but by manual calculation with the sobel test formula. The results of calculating the $\mathrm{z}$ value of the sobel test are:

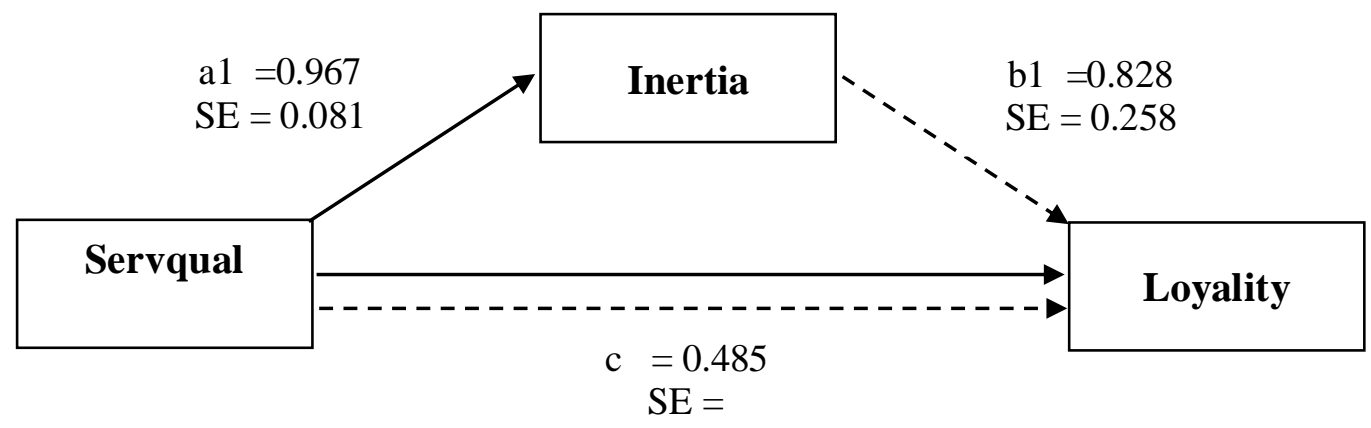

Figure 4.Testing The Effect of Inertia as a Mediation 


\section{International Journal of Business Management and Economic Review}

Vol. 4, No. 02; 2021

ISSN: 2581-4664

$$
\begin{gathered}
z 1=\frac{a 1 b 1}{\sqrt{b 1^{2} S E_{a}^{2}+a 1^{2} S E_{b}^{2}}} \\
z=3,099
\end{gathered}
$$

From the calculation of the sobel test above, the $\mathrm{z}$ value is $3.099>1.976$ with a significance level of $0.0019<0.05$. These results indicate that there is an indirect influence between servqual and loyalty which is mediated by inertia. Thus it can be stated that the hypothesis Ha7 is accepted, namely that inertia behavior mediates the relationship of servqual to Bukalapak's consumer loyalty in the city of Banda Aceh.

Furthermore, the effect/relationship will be explained from before the mediation effect to after the mediation effect (Satisfaction) with the Baron and Kenny approach between the servqual variables towards loyalty which can be seen in table 6 below. Based on the success of the regression analysis in table 6 , it is identified that in model 1 there is a relationship positive and significant between the variables of servqual to loyalty, which is indicated by $\beta 1=0.912$, and Sig $<0.05$. When the relationship between servqual and loyalty is included in the mediating variable in model 2 , namely satisfaction, it shows a significant relationship $(\beta 2=0.347, \mathrm{p}<0.05)$. The description above also provides information about changes in the $\beta$ value of the first servqual which was previously 0.912 ; after entering the mediating variable, the $\beta$ value of servqual became 0.347. Based on the above results associated with the method of Baron and Kenny, it can be explained that the satisfaction variable has a role as a partial mediation (Partial Mediation). This is because the relationship between the servqual variable and the loyalty variable before and after the inclusion of the mediating variable is equally significant. This supports the hypothesis that has been put forward in this study.

\begin{tabular}{|c|c|c|c|c|c|c|}
\hline \multicolumn{2}{|c|}{ Model } & $\begin{array}{l}\text { Unstandardized } \\
\text { Coefficients } \\
\text { B }\end{array}$ & \multicolumn{2}{|c|}{$\begin{array}{l}\text { Standardized } \\
\text { Coefficients } \\
\text { Std. Error }\end{array}$} & Sig. & \multirow[b]{2}{*}{.367} \\
\hline 1 & (Constant) & -.709 & .783 & $\begin{array}{l}\mathrm{t} \\
\text { Beta } \\
\end{array}$ & -.905 & \\
\hline & E-Servqual & .439 & .016 & .912 & 27.105 & .000 \\
\hline \multirow[t]{3}{*}{2} & (Constant) & -2.446 & .602 & & -4.067 & .000 \\
\hline & E-Servqual & . 167 & .027 & . 347 & 6.092 & .000 \\
\hline & Satisfaction & .878 & .079 & .629 & 11.044 & .000 \\
\hline
\end{tabular}

Table 6. Results of Regression Analysis on the Effect of Satisfaction Mediation 


\section{International Journal of Business Management and Economic Review}

Vol. 4, No. 02; 2021

ISSN: 2581-4664

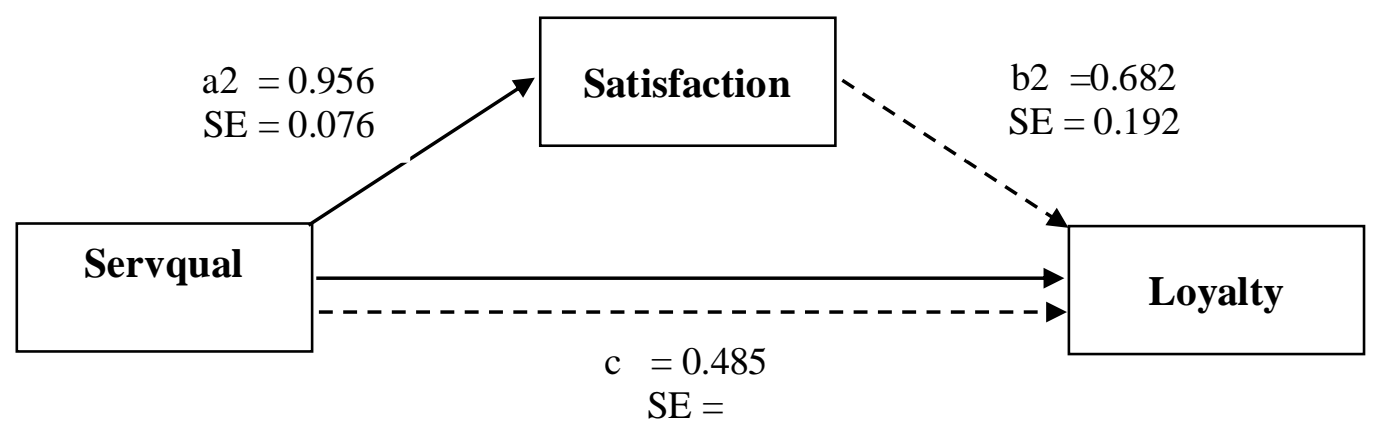

Figure 5.Testing the Effect of Satisfaction as a Mediation

The following is the testing of the mediating effect of the satisfaction variable carried out by the Sobel Test procedure which can be explained as follows. Based on Figure 6 above is a model formed from the results of the first and second regressions so as to form a path analysis model with the satisfaction variable as the mediator. The results of calculating the $\mathrm{z}$ value of the sobel test are:

$$
\begin{gathered}
z 2=\frac{a 2 b 2}{\sqrt{b 2^{2} S E_{a}^{2}+a 2^{2} S E_{b}^{2}}} \\
z=3,418
\end{gathered}
$$

From the calculation of the sobel test above, the $\mathrm{z}$ value is $3.418>1.976$ with a significance level of $0.0006<0.05$. These results indicate that there is an indirect effect between servqual and loyalty mediated by partial satisfaction (partial mediation). Thus it can be stated that the hypothesis $\mathrm{Ha8}$ is accepted, namely satisfaction mediates the relationship between servqual and customer loyalty Bukalapak in Banda Aceh City.

\subsection{Discussion of Hypothesis Results}

Based on the results of the tests that have been carried out, the following is the recapitulation of the hypothesis testing that has been analyzed using a structural model (SEM) using AMOS analysis tools as in table 7 below Based on table 7, it can be seen that the results of testing the first hypothesis show that all variables in this study, namely loyalty, inertia behavior, satisfaction, and servqual are considered good by Bukalapak consumers in Banda Aceh City. In the loyalty assessment, the statement with the lowest score was "I encourage friends and relatives to use Bukalapak". This explains that Bukalapak's loyal consumers still have to continue to encourage and convince friends and relatives to use Bukalapak in shopping because Bukalapak itself has provided various goods to meet the needs of its consumers. In the assessment of inertia behavior, the statement that scored the lowest was "The cost of time, money and effort to switch to other e-commerce sites is high/large". Consumers assess the cost of time, money, and effort is not a big thing in valuing other e-commerce. 


\section{International Journal of Business Management and Economic Review}

Vol. 4, No. 02; 2021

ISSN: 2581-4664

\section{Table 7. Recapitulation of Hypothesis Test Results}

\begin{tabular}{|l|l|l|l|l|l|l|}
\hline No & Hypothesis Statement & $\begin{array}{l}\text { Estimate } \\
\text { Std. }\end{array}$ & S.E. & CR & P & $\begin{array}{l}\text { Hypothes } \\
\text { is }\end{array}$ \\
\hline $\mathbf{1}$ & $\begin{array}{l}\text { Servqual, inertia behavior, satisfaction, and } \\
\text { consumer loyalty are good. }\end{array}$ & - & - & - & $*$ & received \\
\hline $\mathbf{2}$ & $\begin{array}{l}\text { Servqualsignificantly affects inertia } \\
\text { behavior. }\end{array}$ & $\mathbf{. 9 6 7}$ & $\mathbf{0 . 0 8 1}$ & $\mathbf{1 5 . 2 9 4}$ & $* * *$ & received \\
\hline $\mathbf{3}$ & Servqualsignificantly affects satisfaction. & $\mathbf{. 5 5 6}$ & $\mathbf{. 0 7 6}$ & $\mathbf{1 4 . 7 6 4}$ & $* * *$ & received \\
\hline $\mathbf{4}$ & Inertia behavior significantly affects loyalty. & $\mathbf{. 8 2 8}$ & $\mathbf{. 2 5 8}$ & $\mathbf{3 . 4 9 7}$ & $* * *$ & received \\
\hline $\mathbf{5}$ & Servqualsignificantly affects loyalty. & $\mathbf{. 4 8 5}$ & $\mathbf{. 3 4 3}$ & $\mathbf{1 . 9 7 0}$ & $\mathbf{. 0 4 9}$ & received \\
\hline $\mathbf{6}$ & Satisfaction significantly affects loyalty. & $\mathbf{. 6 8 4}$ & $\mathbf{. 1 9 2}$ & $\mathbf{4 . 1 9 1}$ & $* * *$ & received \\
\hline $\mathbf{7}$ & $\begin{array}{l}\text { Inertia behavior mediates the relationship } \\
\text { between servqual and loyalty. }\end{array}$ & - & $\mathbf{0 . 2 5 8}$ & $\mathbf{3 . 0 9 9}$ & $* * *$ & received \\
\hline $\mathbf{8}$ & $\begin{array}{l}\text { Satisfaction mediates the relationship } \\
\text { between servqual and loyalty. }\end{array}$ & - & $\mathbf{0 . 1 9 0}$ & $\mathbf{3 . 4 1 8}$ & $* * *$ & received \\
\hline
\end{tabular}

Source: Primary Data, 2020 (processed)

Consumers easily access other e-commerce and compare their convenience with Bukalapak. In the satisfaction assessment, the statement with the lowest score was "The Bukalapak application has met my expectations". This needs to be a concern of Bukalapak, to often conduct surveys to their customers regarding what additional features or things must be developed and improved to meet user expectations. By being able to continue to meet the expectations of its users, it will form strong loyalty and build good bonds to the company and its consumers. Furthermore, in the servqual assessment, the statement "Fast Bukalapak service response" has the lowest score. This indicates that consumers want a better and faster response from Bukalapak's customer service. Consumers tend to prefer fast and easy service response in their transactions.

The results of testing the second hypothesis show that the servqual variable significantly affects Bukalapak's consumer inertia behavior in the city of Banda Aceh. For a company that provides the best and quality service to its customers in accordance with expectations, it is very likely that these customers will reuse in the future and continue to use them repeatedly. When customers enter the stage of using the service repeatedly, it will form a habit. After the habit forms the character of the customer without realizing it, inertia behavior will be formed. Inertia behavior is a psychological process in which consumers do not measure the decision process in purchasing and using a product or service, but rather justify the habit of using the same thing. With consistent inertia behavior by customers, it will make them not motivated to look for other alternatives. This is what will form a strong loyalty behavior to a product or service. These results are in accordance with (Adriani \& Warmika, 2019) that provedtheservqual has a positive and significant effect on the intention to reuse consumers who use Go-Jek services. (Dzulfiqar, 2017) also found a similar thing, namely the quality of service has a significant influence on the habit of repurchasing on Cafe trends Bandung. 


\section{International Journal of Business Management and Economic Review}

Vol. 4, No. 02; 2021

ISSN: 2581-4664

The results of testing the third hypothesis show that the servqual variable significantly affects Bukalapak's customer satisfaction in Banda Aceh. Consumers will feel satisfied if the company can provide superior servqual and consistency. The quality of service in e-commerce can be seen on the display side of the website which provides easy and fast information to customers and is interesting. If the company can excel in providing it according to what consumers want, the company will have an edge in the industry. In addition, servqual can also be assessed by customer service who provides responsive, helpful, and willing to respond to customer inquiries quickly. Consumers who have problems in their online transactions will be greatly helped by the help of customer service. Consumers will be satisfied with a website if the problem can be resolved. Therefore it is important for customer service to provide the best service because it will determine whether consumers are satisfied or not and form the company's image. The results of this study are in accordance with (Indra et al., 2019) which proved that servqualsignificantly affects customer satisfaction of GrabCar online transportation. Other research also conducted by (Irwansyah \& Mappadeceng, 2018) proves that e-servqual has a direct effect on customer satisfaction of Buka Indonesia consumers. The results of a similar study were also found by (Nyan et al., 2020) which showed that servqual is a strong predictor of customer satisfaction in the mobile telecommunications industry in Ghana.

The results of testing the fourth hypothesis show that inertia behavior significantly affects Bukalapak's consumer loyalty in Banda Aceh. When the level of inertia of a customer increases, it shows a tendency to buy a certain product several times. This is because customers may feel uncomfortable about the time and investment it takes to make different choices on multiple ecommerce sites. Consumers who have inertia behavior are less motivated to consider other ecommerce alternatives. The inertia behavior itself makes consumers avoid looking for further information related to products from unfamiliar websites so that consumers with high inertia will be loyal to the products and services they are currently using. and will repeat the purchase by itself. Due to habit, inertia consumers unconsciously become loyal to product and service providers and make repeat purchases without much thought. The results of this study are in accordance with the research of (Gonçalves et al., 2020) showed that inertia significantly affects loyalty and has a stronger effect in health care than in other service sectors. In addition, (Kuo et al., 2013) research also showed that consumer inertia and satisfaction positively affect repurchase intention, and consumer inertia is more influential than satisfaction in female consumers at 2 Taiwanese universities who shop online. Research by (Rohman et al., 2019) also found that inertia had a significant effect on the shopping loyalty of Economics and Business students at the Islamic University of Malang in e-commerce.

The results of testing the fifth hypothesis show that servqualsignificantly affects Bukalapak's consumer loyalty in Banda Aceh. To ensure customer loyalty, efficient servqual is needed to achieve the desired results. The quality of service will depend on the ability of service providers to meet consumer expectations and desires (Nyan et al., 2020). A company must realize and pay attention to how to create and improve the quality of services offered will form loyalty. In a customer-oriented industry or business, it cannot be avoided that servqual is the only determining factor for the existence of the company or industry in an industry or business that is full of competition, because if servqual is not considered, then the consequence is that customers will move to the industry or other similar businesses that provide better service. The results of this study are in accordance with (Irwansyah \& Mappadeceng, 2018) who explained in his 


\section{International Journal of Business Management and Economic Review}

Vol. 4, No. 02; 2021

ISSN: 2581-4664

research that e-servqual has a direct effect on Bukalapak Indonesia's consumer customer loyalty. The same result was also found by (Hasanuddin, Rachma, \& Wahono, 2020) who explained that servqual and customer trust had a positive and significant effect on customer loyalty at Mr Beard Coffee Café. Research by (Nyan et al., 2020) also showed that servqual is a significant positive predictor of customer loyalty in the mobile telecommunications industry in Ghana.

The results of testing the sixth hypothesis show that satisfaction significantly affects Bukalapak's consumer loyalty in the city of Banda Aceh. Customers who are satisfied with a website will form a loyal nature. They will be more willing to interact with these websites in the future. Satisfied customers will usually avoid seeking uncertainty about whether a customer can receive the same satisfaction and service from other websites. This is what also triggers customers to stay loyal to use the same website in the future. Customer satisfaction creates customer retention (consumer retention) which in turn creates loyalty and can increase company profits, given the cost of retaining existing customers is cheaper than the cost of finding new customers. The results of this study are in accordance with (Gani, 2018) which also proved that e-Satisfaction and e-Trust have a positive and significant effect on e-Loyalty in female consumers who make online shopping transactions. Similar results were also found in (Rafiah, 2019) study where customer satisfaction and customer trust have a significant and positive effect on e-commerce consumer loyalty. Research by (Rohman et al., 2019) also found that satisfaction significantly affects the shopping loyalty of students of the Faculty of Economics and Business, the Islamic University of Malang in e-commerce.

The results of testing the seventh hypothesis show that inertia behavior mediates the relationship between servqual and consumer loyalty of Bukalapak in Banda Aceh. if the quality of service is in accordance with the wishes, the quality of service can be perceived as good. When customers continue to use them again and have used them repeatedly, it will become a habit, then inertia will appear. By continuing to increase inertia behavior in a product, loyalty will be formed. When consumers are in a state of high inertia, sustainable and loyal purchasing behavior will occur even though at one time consumers feel dissatisfied with the quality of service they receive at the same time. This result is also found in the research of (Amoroso et al., 2017)that provedthe inertia is the strongest factor among all constructs in predicting consumer loyalty and continuation intention, either as a mediator variable or directly in mobile wallet application users in Thailand. In addition, Ching Chan Cheng (2011) also found that apart from being positively influenced by customer satisfaction, customer loyalty will be more influenced by inertia in the fast-food industry in Taiwan.

Furthermore, the results of testing the eighth hypothesis show that satisfaction mediates the relationship of servqual to Bukalapak's consumer loyalty in the city of Banda Aceh. In website-based services, companies that provide the best quality service to customers will shape the satisfaction felt by consumers, and in the long run will result in loyalty behavior. In addition to having an impact on satisfaction, servqual can also form a more harmonious relationship between a company and its customers (Nyan et al., 2020). When consumers have experienced good and friendly servqual, and feel satisfaction with the quality of service provided to these products, these consumers will give positive characteristics. When a positive character has emerged, there will be a sense of loyalty. (Irwansyah \& Mappadeceng, 2018) also proved the same result, namely e-servqual has an effect on customer loyalty through consumer satisfaction, Bukalapak Indonesia consumers. Other research conducted by Zulfiqar Ari Research by (Nyan et 


\section{International Journal of Business Management and Economic Review}

Vol. 4, No. 02; 2021

ISSN: 2581-4664

al., 2020) also proved that customer satisfaction mediates the effect of servqual on customer loyalty in the cellular telecommunications industry in Ghana. Similar research conducted by (Narotama, 2019) found a mediating effect of customer satisfaction in the relationship of servqual to customer loyalty.

\section{CONCLUSION AND RECOMMENDATIONS}

Based on the results of the research and discussion described in the previous chapter, the following conclusions can be drawn:

1. Servqual, inertia behavior, satisfaction, and consumer loyalty at Bukalapak are already good based on community assessments in Banda Aceh City.

2. Servqualsignificantly affects the inertia behavior of Bukalapak consumers in Banda Aceh City.

3. Servqualsignificantly affects Bukalapak's customer satisfaction in Banda Aceh.

4. Inertia significantly affects Bukalapak's consumer loyalty in the city of Banda Aceh.

5. Servqualsignificantly affects Bukalapak's consumer loyalty in Banda Aceh.

6. Satisfaction significantly affects Bukalapak's consumer loyalty in the city of Banda Aceh.

7. Inertia behavior mediates the relationship between servqual and consumer loyalty of Bukalapak in Banda Aceh.

8. Satisfaction mediates the relationship between servqual and customer loyalty in Bukalapak in Banda Aceh.

Based on the conclusions from a series of tests on the variables in this study, several results can be suggested as follows:

1. Bukalapak company is expected to continue to improve and innovate in its customer loyalty strategy which aims to increase the intention and interest of its customers. By maintaining customer loyalty Bukalapak will continue to have a competitive advantage.

2. Bukalapak company can also pay more attention to the future regarding customer service so that it can respond more quickly to consumer problems.

3. Bukalapak company is expected to continue to innovate on its attractive and unique application features so that consumers find it difficult or reluctant to switch to other ecommerce sites.

4. The Bukalapak company can also conduct regular surveys to its customers regarding the expectations that consumers want in the future for the Bukalapak application so that it can become material for Bukalapak's research and development in maintaining satisfaction.

5. It is hoped that the next researchers will examine other variables that influence inertia behavior and will have an impact on e-commerce consumer loyalty. In addition, they can also compare how the inertia behavior affects various other e-commerce. Further researchers also are expected to be able to develop this tested model by adding moderation variables such as gender proportions, namely men and women that can affect customer loyalty of e-commerce. 
International Journal of Business Management and Economic Review

Vol. 4, No. 02; 2021

ISSN: 2581-4664

\section{REFERENCES}

Adriani, N. N., \& Warmika, I. G. K. (2019). Pengaruh Kualitas Pelayanan \& Persepsi Nilai Terhadap Kepuasan \& Niat Menggunakan Kembali. E-Jurnal Manajemen, 8(4), 19561984. https://doi.org/https://doi.org/10.24843/EJMUNUD.2019.v08.i04.p03

Alzoubi, H. M., Abdo, M., Al-Gasaymeh, A., \& Alzoubi, A. A. (2019). An empirical study of eService quality and its impact on achieving a value added. Journal of Business and Retail Management Research, 13(4), 138-145. https://doi.org/https://doi.org/10.24052/JBRMR/V13IS04/ART-12

Amoroso, D. L., Ackaradejruangsri, P. G., \& Lim, R. A. (2017). The Impact of Inertia as Mediator and Antecedent on Consumer Loyalty and Continuance Intention. International Journal of Customer Relationship Marketing and Management (IJCRMM), 8(2), 960-981. https://doi.org/10.4018/IJCRMM.2017040101

Anderson, R. E., \& Swaminathan, S. (2011). Customer Satisfaction \& Loyalty In E-Markets: a PLS Path Modeling Approach. Journal of Marketing Theory and Practice, 19(2), 221-234. https://doi.org/https://doi.org/10.2753/MTP1069-6679190207

Baron, R. M., \& Kenny, D. A. (1986). The moderator-mediator variable distinction in social psychological research: Conceptual, strategic, and statistical considerations. Journal of Personality and Social Psychology, 51(6), 1173-1182. https://doi.org/10.1037//00223514.51.6.1173

Dewi, A. F. R. (2019). Pengaruh Gamifikasi Pada Program Loyalitas Terhadap Loyalitas Pengguna Marketplace Dengan Menggunakan Expectation-Confirmation Model (Ecm). Universitas Islam Negeri Syarif Hidayatullah Jakarta.

Dzulfiqar, I. (2017). Pengaruh Suasana Cafe \& Kualitas Pelayanan Terhadap Pembelian Ulang (Survey Pada Konsumen Trends Cafe Bandung). Jurnal Manajemen. Fakultas Ekonomi Universitas Komputer Indonesia. Retrieved from https://elib.unikom.ac.id/files/disk1/694/jbptunikompp-gdl-irfandzulf-34692-1-unikom_i1.pdf

Ercis, A., Yildiz, T., \& Deveci, F. G. (2018). The effect of inertia and satisfaction on consumer loyalty in online shopping sites. Journal of Management, Marketing and Logistic, 5(3), 214-225. https://doi.org/: http://doi.org/10.17261/Pressacademia.2018.965

F. Hair Jr, J., Sarstedt, M., Hopkins, L., \& G. Kuppelwieser, V. (2014). Partial least squares structural equation modeling (PLS-SEM) An emerging tool in business research. European Business Review, 26(2), 106-121.

Fahrika, A., Rachma, N., \& Slamet, A. R. (2019). Pengaruh Online Marketing \& E-Service Quality Terhadap Loyalitas Dengan Kepuasan Sebagai Variabel Intervening Pada Online Shop Joyism Malang. Jurnal Ilmiah Riset Manajemen, 8(4), 52-63.

Ferdinand, A. (2014). Metode Penelitian Manajemen (Edisi 5). Semarang: Universitas Diponegoro. 


\section{International Journal of Business Management and Economic Review}

Vol. 4, No. 02; 2021

ISSN: 2581-4664

Fida, B. A., Ahmed, U., Al-Balushi, Y., \& Singh, D. (2020). Impact of Service Quality on Customer Loyalty and Customer Satisfaction in Islamic Banks in the Sultanate of Oman. Sage Open, 10(2), 1-10. https://doi.org/https://doi.org/10.1177/2158244020919517

Gani, R. (2018). Peran Perantara E-Kepuasan \& E-Kepercayaan Pada Pengembangan ELoyalitas Dalam Konteks Bisnis Online Pada Pembelanja Online Wanita. Universitas Islam Indonesia.

Ghozali, I. (2017). Model Persamaan Struktural, Konsep dan Aplikasi dengan Program AMOS 24 Update Bayesian SEM (Edisi 7). Semarang: Badan Penerbit Universitas Diponegoro.

Gonçalves, F. M. R. R., Cândido, C. J. F., \& Feliciano, I. M. P. L. (2020). Inertia, group conformity and customer loyalty in healthcare in the information age. Journal of Service Theory and Practice, 30(3), 307-330. https://doi.org/https://doi.org/10.1108/JSTP-08-20190184

Gray, D. M., D’Alessandro, S., Johnson, L. W., \& Carter, L. (2017). Inertia in services: causes and consequences for switching. Journal of Services Marketing, 31(6), 485-498. https://doi.org/https://doi.org/10.1108/JSM-12-2014-0408

Hasanuddin, M. R., Rachma, N., \& Wahono, B. (2020). Pengaruh Kualitas Produk, Kualitas Pelayanan Dan Kepercayaan Pelanggan Terhadap Loyalitas Pelanggan (Pada Pelanggan Kedai Kopi Mr Beard Coffee Jl, Saxophone No. 47 Tunggul Wulung Lowokwaru Malang). Jurnal Ilmiah Riset Manajemen, 9(11), 39-53.

Hsu, C.-L., \& Lin, J. C.-C. (2015). What drives purchase intention for paid mobile apps? - An expectation confirmation model with perceived value. Electronic Commerce Research and Applications, 14(1), 46-57. https://doi.org/https://doi.org/10.1016/j.elerap.2014.11.003

Hu, H.-Y., Cheng, C.-C., Chiu, S.-I., \& Hong, F.-Y. (2011). A study of customer satisfaction, customer loyalty and quality attributes in Taiwan's medical service industry. African Journal of Business Management, 5, 187-195.

Ida Aju Brahmasari, H., Dipl, D., \& Panjaitan, H. (2016). The Influence of Service Quality, and Customer Relationship Management (CRM) Of Patient Satisfaction, Brand Image, Trust, and Patient Loyalty on Indonesian National Army Level II Hospitals. International Journal of Business and Management Invention ISSN, 5(5), 30-44.

Indra, D., Regita, R., \& Purba, J. T. (2019). Pengukuran Kualitas Pelayanan, Harga \& Customer Value Terhadap Kepuasan Pelanggan Transportasi Online Bagi Kaum Millenial. Journal of Accounting and Management Innovation, 3(1), 14-31.

Irwansyah, A., \& Mappadeceng, R. (2018). Pengaruh E-Service Quality Terhadap Customer Loyalty Melalui Customer Satisfaction Pada Toko On Line Buka Lapak. J-MAS (Jurnal Manajemen Dan Sains), 3(2), 128-136. https://doi.org/10.33087/jmas.v3i2.50

Iskandar, A. R. (2017). Analisis Pengaruh Kepuasan Layanan Website Terhadap Loyalitas Konsumen E-Commerce Bukalapak.Com. Institut Pertanian Bogor.

Isnainiyah, M., Rachma, N., \& Hufron, M. (2019). Analisis Dampak Kualitas Pelayanan \& Kepuasan Sebagai Moderating Variabel Terhadap Loyalitas Nasabah Bank BRI Kantor Kas 


\section{International Journal of Business Management and Economic Review}

Vol. 4, No. 02; 2021

ISSN: 2581-4664

\section{Unisma. Jurnal Ilmiah Riset Manajemen, 8(6), 139-154.}

Kotler, P., \& Keller, K. L. (2018). Marketing Management, Global Edition (15th editi). Harlow, United Kingdom: Pearson.

Kuo, Y., Hu, T., \& Yang, S. (2013). Effects of inertia and satisfaction in female online shoppers on repeat-purchase intention: The moderating roles of word-of-mouth and alternative attraction. Managing Service Quality: An International Journal, 23(3), 168-187. https://doi.org/https://doi.org/10.1108/09604521311312219

Lee, J., Hwang, H., Tran, A. T. K., \& Keel, A. (2019). The mediation effect of inertia on service duration. Journal of Applied Structural Equation Modeling, 3(1), 1-14. https://doi.org/10.47263/JASEM.3(1)02

Li, Z., Hu, Y., Ranasinghe, R., Li, J., \& Cui, R. (2017). Structural relationships between inertia, satisfaction, loyalty and revisit behaviour: empirical evidence from local tourists in Chengdu. International Journal of Leisure and Tourism Marketing, 5(3), 248-270. https://doi.org/10.1504/IJLTM.2017.086442

Lie, D., Sudirman, A., Efendi, \& Butarbutar, M. (2019). Analysis of Mediation Effect Of Consumer Satisfaction On The Effect Of Service Quality, Price and Consumer Trust On Consumer Loyalty. International Journal of Scientific \& Technology Research, 8(8), 421428.

Lorena, S. (2018). Pengaruh E-service Quality terhadap E-satisfaction yang berdampak pada Eloyalty (Studi pada Situs Belanja Online Bukalapak.com). Universitas Lampung.

Masood, O., Javaria, K., \& Awan, M. A. (2016). Inertia \& Online Trust Leading Factors Affecting Consumer Repeat-Purchase Intention In E-Commerce (Moderating Role Of Alternative Attraction). Journal of Internet Banking and Commerce, S5.

Narotama, A. (2019). The Effect of Service Quality on Customer Loyalty with Brand Images and Customer Satisfaction as Mediation. Jurnal Manajemen \& Kewirausahaan, 7(1), 86-93. https://doi.org/https://doi.org/10.26905/jmdk.v7i1.2692

Nisar, T. M., \& Whitehead, C. (2016). Brand interactions and social media: Enhancing user loyalty through social networking sites. Computers in Human Behavior, 62, 743-753. https://doi.org/https://doi.org/10.1016/j.chb.2016.04.042

Novandy, Rachma, N., \& Slamet, A. R. (2017). Pengaruh Kualitas Pelayanan Terhadap Loyalitas Dengan Kepuasan Sebagai Variabel Intervening Pada Pelanggan Ramayana Department Store Mall Dinoyo City Malang. Jurnal Ilmiah Riset Manajemen, 6(7), 1-12.

Nyan, L. M., Rockson, S. B., \& Addo, P. K. (2020). The Mediation Effect of Customer Satisfaction on the Relationship Between Service Quality and Customer Loyalty. Journal of Management and Strategy, 11(3), 13-27. https://doi.org/https://doi.org/10.5430/jms.v11n3p13

Prasetyo, M. S. (2016). Pengaruh Perceived Organizational Support Dan Kepuasan Kerja Terhadap Organizational Citizenship Behavior Pada Karyawan Bagian Rumah Tangga Universitas Negeri Yogyakarta. Jurnal Manajemen Bisnis Indonesia, 5(6), 562-573. 


\section{International Journal of Business Management and Economic Review}

Vol. 4, No. 02; 2021

ISSN: 2581-4664

Rafiah, K. K. (2019). Analisis Pengaruh Kepuasan Pelanggan dan Kepercayaan Pelanggan terhadap Loyalitas Pelanggan dalam Berbelanja melalui E-commerce di Indonesia. Al Tijarah, 5(1), 46-56. https://doi.org/http://dx.doi.org/10.21111/tijarah.v5i1.3621

Rahayu, E. (2018). Pengaruh E-Service Quality Terhadap E-Customer Satisfaction \& ECustomer Loyalty Pada Toko Online Shopee. Universitas Islam Negeri Syarief Hidayatullah.

Riduwan, \& Kuncoro, E. A. (2014). Cara Menggunakan dan Memaknai Analisis Jalur (Path Analysis) (Cet. 6). Bandung: Alfabeta.

Rohman, A. F., Rachma, N., \& Slamet, A. R. (2019). Pengaruh Nilai, Kepuasan, \& Inersia Terhadap Loyalitas Pelanggan Yang Berbelanja Melalui E-Commerce Pada Mahasiswa FEB Universitas Islam Malang. Jurnal Ilmiah Riset Manajemen, 8(10), 25-38.

Salah, M. R. (2019). Comprehensive Evaluation of E-Service Quality Determinants. "Studying the Impact of these Key Quality Determinants On The Satisfaction and Loyalty of Online Jordanian Customers." European Journal of Business and Management, 11(12), 202-233. https://doi.org/10.7176/EJBM/11-12-24

Santoso, S. (2014). Statistik Multivariat: Konsep dan Aplikasi dengan SPSS (Ed. Revisi). Jakarta: Elex Media Komputindo.

Setyowati, D., \& Suryoko, S. (2020). Pengaruh E-Service Quality Terhadap Keputusan Pembelian Melalui E-Trust Sebagai Variabel Mediasi (Studi Pada Pengguna Situs Bukalapak Di Kota Semarang). Jurnal Ilmu Administrasi Bisnis, 9(1), 251-260.

Sobel, M. E. (1982). Asymptotic Confidence Intervals for Indirect Effects in Structural Equation Models. Sociological Methodology, 290-321. https://doi.org/https://doi.org/10.2307/270723

Solimun, \& Fernandes, A. A. R. (2018). The mediation effect of customer satisfaction in the relationship between service quality, service orientation, and marketing mix strategy to customer loyalty. Journal of Management Development, 37(1), 76-87. https://doi.org/https://doi.org/10.1108/JMD-12-2016-0315

Sudjana. (2002). Metode statistika. Bandung: Tarsito.

Susanto, H., Rachma, N., \& Hufron, M. (2018). Pengaruh Service Quality Terhadap Customer Loyalty Melalui Kepuasan Sebagai Variabel Intervening (Studi Kasus Pada Anggota Simpan Pinjam KUD Pakis Malang). Jurnal Ilmiah Riset Manajemen, 7(7), 21-33.

Tsai, M.-C., \& Lin, J.-C. (2017). The Influence Of Inertia On Repurchase Intention Of Hypermarket Customers. International Journal of Economic and Research, 8(2), 41-67.

Wang, W.-T., Ou, W.-M., \& Chen, W.-Y. (2019). The impact of inertia and user satisfaction on the continuance intentions to use mobile communication applications: A mobile service quality perspective. International Journal of Information Management, 44, 178-193. https://doi.org/https://doi.org/10.1016/j.ijinfomgt.2018.10.011

Wicaksono, Z. A., \& Untoro, W. (2015). Pengaruh Kualitas Layanan dan Kewajaran Harga Yang 
International Journal of Business Management and Economic Review

Vol. 4, No. 02; 2021

ISSN: 2581-4664

Dirasakan Terhadap Loyalitas Pelanggan Dimediasi oleh Kepuasan Pelanggan. Fokus Manajerial, 13(2), 121-132.

Xu, F., \& Du, J. T. (2018). Factors influencing users' satisfaction and loyalty to digital libraries in Chinese universities. Computers in Human Behavior, 83, 64-72. https://doi.org/https://doi.org/10.1016/j.chb.2018.01.029 